\title{
WPŁYW EMBARGA FEDERACJI ROSYJSKIEJ NA EKSPORT JABŁEK Z POLSKI W LATACH 2004-2015
}

\author{
Adam A. Ambroziak \\ Katedra Integracji Europejskiej im. J. Monneta Szkoły Głównej Handlowej w Warszawie \\ Kierownik katedry: prof. dr hab. Elżbieta Kawecka-Wyrzykowska
}

\begin{abstract}
Słowa kluczowe: embargo, eksport, import, Polska, Federacja Rosyjska, jabłka Key words: embargo, export, import, Poland, Russian Federation, apples

S y n o p s i s. W sierpniu 2014 r. Federacja Rosyjska nałożyła embargo na przywóz wielu artykułów rolno-spożywczych m.in. z państw członkowskich Unii Europejskiej, w tym z Polski. W przypadku Polski było to drugie embargo nałożone po akcesji do Unii Europejskiej. Celem badania była ocena konsekwencji nałożenia przez Federację Rosyjską zakazów importu z Polski jednego z istotniejszych artykułów rolno-spożywczych - jabłek w latach 2004-2015. W badaniu określono zmianę struktury geograficznej polskiego eksportu jabłek i pozycję konkurencyjną na tle innych państw członkowskich (wskaźniki przewagi komparatywnej (RCA) oraz indeks przewagi w handlu Lafaya). W okresie pierwszego embarga nie było konieczności poszukiwania rynków zbytu poza Rosją w sytuacji braku problemów z reeksportem poprzez inne kraje (w tym przede wszystkim Litwę). W okresie drugiego embarga rosyjskiego zakaz dotyczył całej UE, co ograniczało możliwość reeksportu przez państwa unijne. W konsekwencji Polska szukała nowych rynków zbytu, w tym na jednolity rynek europejski.
\end{abstract}

\section{WPROWADZENIE}

W sierpniu 2014 r. Federacja Rosyjska nałożyła drugie od rozszerzenia Unii Europejskiej (UE) w 2004 r. ograniczenie w formie embarga na przywóz wielu artykułów rolno-spożywczych z Polski. Jest to przykład środka retorsji w odpowiedzi na wcześniej nałożone przez UE sankcje na Rosję w związku z konfliktem na Ukrainie. Abstrahując od politycznych przesłanek nałożenia tych ograniczeń, mają one także wymierny wpływ na międzynarodową wymianę handlową oraz stan gospodarki zarówno Rosji, jak i państw dotkniętych zakazem importu.

Dotychczasowe badania dotyczące nakładanych ograniczeń przez Federację Rosyjską na import z państw członkowskich UE [Forsberg, Seppo 2009, Mroczek 2014, Kraatz 2014, Kutlina-Dimitrova 2015, Nacewicz-Twardowska 2016, Smutka i in. 2016, Horska i in. 2016, Fedoseeva 2016], w tym z Polski [Błaszczuk-Zawiła 2014, Nacewicz-Twardowska 2015], wykazały ich istotne ekonomiczne konsekwencje dla całej branży rolno-spożywczej [Matysik-Pejas i in. 2010, Cieślewicz 2012, Michalczyk 2012, Ambroziak, Szczepaniak 2014, Ambroziak 2015, Batyk 2014, Malchar-Michalska 2014, Grzegorzewska 2014, Drążek i in. 2015, Batyk 2015, Pawlak 2015, Rosińska-Bukowska 2015, Kraciński 2015]. Jednak niektóre wnioski czy postulaty odnoszące się do całego sektora niekoniecznie są adekwatne dla pojedynczych towarów. 
Biorąc pod uwagę strukturę i wielkość produkcji oraz sprzedaży, do badań wybrano eksport jabłek jako jednego z istotniejszych towarów w polskim handlu, który został dotknięty zakazem rosyjskim [Borowska 2013, Borowska 2014, Bugała 2014].

Celem opracowania jest ocena konsekwencji nałożenia przez Federację Rosyjską środków ograniczających import jabłek z Polski w latach 2004-2015.

\section{METODA BADAWCZA}

Analizie statystycznej handlu poddano pozycję taryfową na poziomie sześciocyfrowym HS: 080810 (jabłka świeże). Za okres badawczy przyjęto lata 2004-2015, tj. czas od momentu akcesu Polski do UE, gdy wprowadzono unijne regulacje wpływające na rynek jabłek w kraju.

W badaniu eksportu jabłek z Polski została określona pozycja Polski jako eksportera tego produktu na tle pozostałych państw członkowskich UE, zmiana struktury geograficznej polskiego eksportu jabłek zarówno w ramach rynku wewnętrznego UE, jak i w handlu poza UE. W badaniu uwzględniono także wskaźniki pozwalające ocenić pozycję konkurencyjną sprzedaży jabłek przez Polskę wewnątrz UE oraz eksportu do państw trzecich: wskaźnik przewagi komparatywnej (RCA) i indeks przewagi w handlu Lafaya.

Przyjęto następujące formuły obliczenia ujawnionej przewagi komparatywnej RCA oraz wskaźnika Lafaya w eksporcie jabłek państw członkowskich UE do państw trzecich oraz sprzedaży wewnątrzunijnej [Balassa 1965, Lafay 1992]:

$$
\mathrm{RCA}_{\mathrm{ex} / \mathrm{inUE} ; \mathrm{y}}^{\mathrm{pcz}}=\frac{\mathrm{x}_{\mathrm{ex} / \mathrm{inUE} ; \mathrm{y}}^{\mathrm{pcz}} / \sum_{\mathrm{i}=1}^{\mathrm{n}} \mathrm{x}_{\mathrm{ex} / \mathrm{inUE} ; \mathrm{y}}^{\mathrm{pcz}}}{\mathrm{x}_{\mathrm{ex} / \mathrm{inUE} ; \mathrm{y}}^{\mathrm{UE}} / \sum_{\mathrm{i}=1}^{\mathrm{n}} \mathrm{x}_{\mathrm{ex} / \text { inUE } \mathrm{y}}^{\mathrm{UE}}}
$$

gdzie: $R C A_{e x / i n U E ; y}^{p c z}$ - wskaźnik ujawnionej przewagi komparatywnej RCA eksportu/wewnątrzunijnej dostawy grupy produktów (grupy produktów $y$ ), $x_{e x / i n U E ; y}^{p c z}$ - wartość eksportu poza UE (exUE)/ wewnątrzunijnej dostawy (inUE) przez państwo członkowskie $(p c z)$ grupy produktów $(y), x_{e x / i n U E ; y}^{U E}$ - wartość eksportu poza UE (exUE)/wewnątrzunijnej dostawy (inUE) przez wszystkie państwa członkowskie UE (UE) grupy produktów (y), $n$ - liczba grup produktów w handlu (owoce (HS 08)).

$$
\begin{aligned}
& \mathrm{LFI}_{\mathrm{exUE} ; \mathrm{y}}^{\mathrm{pcz}}=100 *\left\{\frac{\mathrm{x}_{\mathrm{ex} / \mathrm{inUE} ; \mathrm{y}}^{\mathrm{pcz}}-\mathrm{m}_{\mathrm{ex} / \mathrm{inUE} ; \mathrm{y}}^{\mathrm{pcz}}}{\mathrm{x}_{\mathrm{ex} / \text { inUE; } \mathrm{y}}^{\mathrm{pcz}}+\mathrm{m}_{\mathrm{ex} / \text { inUE;y }}^{\mathrm{pcz}}}-\frac{\sum_{\mathrm{y}=1}^{\mathrm{n}}\left(\mathrm{x}_{\mathrm{ex} / \mathrm{inUE} ; \mathrm{y}}^{\mathrm{pcz}}-\mathrm{m}_{\mathrm{ex} / \mathrm{inUE} ; \mathrm{y}}^{\mathrm{pcz}}\right)}{\sum_{\mathrm{y}=1}^{\mathrm{n}}\left(\mathrm{x}_{\mathrm{ex} / \mathrm{inUE} ; \mathrm{y}}^{\mathrm{pcz}}+\mathrm{m}_{\mathrm{ex} / \text { inUE;y }}^{\mathrm{pcz}}\right)}\right\} * \\
& \frac{\mathrm{x}_{\mathrm{ex} / \text { inUE; } \mathrm{y}}^{\mathrm{pcz}}+\mathrm{m}_{\mathrm{ex} / \mathrm{inUE} ; \mathrm{y}}^{\mathrm{pcz}}}{\sum_{\mathrm{y}=1}^{\mathrm{n}}\left(\mathrm{x}_{\mathrm{ex} / \text { inUE; } \mathrm{y}}^{\mathrm{pcz}}+\mathrm{m}_{\mathrm{ex} / \text { inUE; }}^{\mathrm{pcz}}\right)}
\end{aligned}
$$

gdzie: $L F I_{e x / i n E U ; y}^{p c z}$ - indeks Lafay'a dla eksportu grupy produktów $(y), x_{e x / i n U E ; y}^{p c z}$ - wartość eksportu poza UE (exUE)/wewnątrzunijnej dostawy (inUE) przez państwo członkowskie ( $p c z$ ) grupy produktów $(y), m_{e x / i n U E ; y}^{p c z}$ - wartość importu spoza UE (exUE)/wewnątrzunijnej dostawy (inUE) przez państwo członkowskie ( $p c z)$ grupy produktów $(y), n$ - liczba grup produktów w handlu. 
Wskaźnik RCA określa, czy udział danego towaru (jabłek - HS 080810) w eksporcie danego działu (owoce - HS 08) danego państwa jest wyższy/niższy od udziału tego produktu w sprzedaży wszystkich państw UE do państw trzecich (lub na rynku wewnętrznym). Gdy wskaźnik przyjmuje wartości większe od 1, tzn. udział eksportu danego towaru (jabłek) w eksporcie danego działu (owoców) omawianego kraju do państw trzecich (lub na rynku unijnym) jest wyższy od odpowiedniego udziału w eksporcie całej UE, wówczas badany kraj ma ujawnione przewagi komparatywne w sprzedaży poza UE (lub na rynek UE). W przypadku wskaźnika Lafaya uwzględnia się nie tylko strumienie eksportu, ale i importu danego kraju, a w szczególności charakter salda obrotów handlowych danego produktu i grupy produktów. Nadwyżka w handlu danym produktem jest utożsamiana $\mathrm{z}$ posiadaniem przewag komparatywnych, podczas gdy ujemne saldo - ich brakiem. Jeżeli wartości wskaźnika Lafaya przyjmują wartości powyżej 0, dany kraj ma względem zagranicy przewagę komparatywną w eksporcie analizowanych produktów. Natomiast wartość ujemna oznacza, że badany kraj nie ma przewagi komparatywnej w eksporcie danego produktu. W badaniach ustalano występowanie potencjalnej przewagi komparatywnej jabłek (HS 080810) w eksporcie owoców (HS 08).

\section{TEORETYCZNE PODSTAWY I MECHANIZM DZIAŁANIA SANKCJI}

Z prawnego punktu widzenia indywidualne środki przymusu nakładane są jako sankcje w związku z naruszeniem prawa międzynarodowego. Głównymi celami przemawiającymi za skorzystaniem z tego instrumentu są: a) zmuszenie sprawcy do zaprzestania deliktu, b) zobowiązanie go do niepowtarzania danego aktu w przyszłości i c) likwidacja skutków naruszenia. Sankcje jako jedna z form indywidualnych środków przymusu, czyli z prawnego punktu widzenia zbiorowe środki przeciwko naruszeniom prawa międzynarodowego, podejmowane są przez organizacje międzynarodowe [Czapliński, Wyrozumska 2004]. Można je interpretować jako negatywną reakcję społeczności międzynarodowej na postępowanie państwa naruszającego normy prawa międzynarodowego [Bierzanek, Symonides 2003]. Innym przykładem indywidualnego środka przymusu, zgodnym z prawem międzynarodowym, są retorsje rozumiane jako działalność odwetowa, jaką państwo podejmuje w odpowiedzi na sprzeczne z jego interesami lub nieprzyjazne działanie drugiego państwa [Czapliński, Wyrozumska 2014].

Powyższe instrumenty nieco inaczej są rozpatrywane z ekonomicznego punktu widzenia, aczkolwiek występują te same polityczne powody ich nałożenia, ukierunkowane na zmianę zachowania rządu państwa, przeciwko któremu środki te zostały wymierzone [Barber 1979, Pape 1997, Wiśniewska 2005]. W kontekście społeczno-gospodarczym sankcje mogą być definiowane jako rzeczywiste wprowadzenie lub groźba użycia ekonomicznych środków ograniczających bogactwo dotkniętego nimi państwa w celu zmiany polityki [Porter 1979]. Warto jednak zauważyć, że niektórzy badacze zaliczają sankcje ekonomiczne do zarządzania gospodarczego, przez co prosty do zidentyfikowania cel polityczny staje się wypadkową celów polityczno-społeczno-gospodarczych [Baldwin, Pape 1998]. W konsekwencji często ograniczenia wprowadzane przez dane państwo, w tym eksportowe (np. embarga), są zaliczane do środków polityki handlowej [Malchar-Michalska 2012]. 
Z jednej strony, niektórzy w sankcjach widzą dodatkowe oręże przy prowadzeniu działań zbrojnych lub instrument bezpośrednio poprzedzający właściwą wojnę [Barber 1979]. Natomiast z drugiej strony, pojawiają się głosy, że prawidłowe nałożenie sankcji nie wymaga już dalszej interwencji (w tym zbrojnej), gdyż w przeciwnym razie sens ich wdrażania byłby wątpliwy [Tsebelis 1990]. Stąd też, oprócz sankcji, wymienia się wojny handlowe oraz wojny gospodarcze (w celu wyniszczenia partnera, często przed konfliktem zbrojnym lub w jego trakcie) [Pape 1997].

Wydaje się, że pojęcie sankcji sprowadza się w dużej mierze do określenia celu, który przyświeca ich twórcom. Można zatem wyróżnić trzy kategorie celów sankcji: a) związane z działaniami i zachowaniem rządów państwa, przeciwko któremu są nakładane, b) dotyczące roli, zachowania i oczekiwań strony nakładającej sankcje oraz c) dotyczące szerszego międzynarodowego kontekstu, struktury czy zadań systemu powiązań, w których dane państwo działa [Barber 1979]. Istnieje wiele klasyfikacji sankcji. Można je podzielić ze względu na zakres przedmiotowy na: a) dyplomatyczne, w postaci odwołania lub wydalenia ambasadorów, niekontynuowania stosunków dyplomatycznych, b) finansowe, w formie zaniechania pomocy finansowej, sprzeciwu względem pożyczek międzynarodowych, zakazów inwestowania czy też zamrożenia aktywów państwa, c) handlowe, w postaci ograniczeń w eksporcie/imporcie, embarga oraz d) inteligentne (ang. smart), dotyczące pojedynczych osób fizycznych lub prawnych (zakazy wjazdu, zamrażanie aktywów) [Kholodilin i in. 2014, Pape 1997]. Sankcje, uwzględniając pozycję negocjacyjną i współzależność partnerów [Keohane, Nye 1987, Morgan, Schebach 1997], można podzielić na negatywne (których efektem jest spadek handlu, produkcji i konsumpcji) i pozytywne (ukierunkowane na wspieranie kooperacji i integracji między państwami) [Wagner 1988, Caruso 2003].

Przyjmuje się dość powszechnie, że im wyższe są koszty państwa, przeciwko któremu są skierowane sankcje, tym wyższe jest prawdopodobieństwo ich skuteczności. Ponadto koszty sankcji dla państwa, na które są one nałożone, są tym wyższe, im obie strony są bardziej zintegrowane, a ich gospodarki powiązane/współzależne [Mayall 1984, van Bergeijk 1994, Tsebelis 1990, Bonetti 1998, Kholodilin i in. 2014]. Niektórzy zauważają jednak, że ograniczenie bilateralnej wymiany handlowej niekoniecznie negatywnie wpływa na ogólny import i eksport państwa dotkniętego sankcjami. Może ono bowiem zmienić kierunek swojego handlu i dostosować się do nowej sytuacji [Drezner 2000]. Ponadto o skuteczności nałożonych sankcji decyduje również wielkość państwa, które jest nimi dotknięte. W przypadku dużego kraju możliwość substytucji np. importu wewnętrzną produkcją, jest znacznie większa niż w małym państwie [Kholodilin i in. 2014, Caruso 2003]. Również czas może ogrywać rolę, gdyż stopniowanie sankcji (zamiast natychmiastowego i pełnego wprowadzenia) powoduje, że gospodarka stopniowo dostosowuje się do nowych sytuacji [Tsebelis 1990]. Także wydłużanie czasu obowiązywania sankcji drastycznie obniża ich efektywność [van Bergeijk 1989], podobnie jak zbyt częste stosowanie [Morgan, Schebach 1997]. Dlatego warto określić skutki nałożenia sankcji na import do Rosji polskich jabłek. Szczególnie ważnym wątkiem jest poziom wzajemnej integracji i uzależnienia dostawcy (Polski) od odbiorcy (Federacji Rosyjskiej), a także dalszych konsekwencji i wpływu na wymianę handlową jabłkami z innymi partnerami gospodarczymi na świecie. 


\section{ZAKAZY IMPORTU JABŁEK Z POLSKI NA RYNEK ROSYJSKI W LATACH 2004-2015}

Federacja Rosyjska nałożyła pierwsze embargo na import jabłek z Polski 14 listopada 2005 r., uzasadniając to fałszowaniem świadectw fitosanitarnych. Zakres tego embarga obejmował produkty roślinne, w tym jabłka. Powodem tego było, według ekspertów, wprowadzenie przez Rosję tak wyśrubowanych norm, że większość dostawców nie była w stanie im sprostać, co udowodniono na partii polskich jabłek [Rosja ... 2008a].

W celu wyeliminowania podstaw do tych zarzutów Polska wprowadziła takie procedury, które poprzez zwiększanie nadzoru służb inspekcyjnych eliminowałyby przypadki nieprawidłowości przy eksporcie m.in. produktów pochodzenia roślinnego (w tym dodatkowe zabezpieczenie świadectw fitosanitarnych, obowiązek plombowania przesyłek po przeprowadzeniu kontroli fitosanitarnej) [Odpowiedź... 2006]. Ponadto rozpoczęto wówczas dwustronne rozmowy między Polską a Federacją Rosyjską, przy wsparciu Komisji Europejskiej (KE), na temat wspólnych kontroli fitosanitarnych. Włączenie się instytucji unijnych w ten spór wynikało m.in. z zablokowania przez Rząd RP przyjęcia mandatu negocjacyjnego na rozmowy o umowie o partnerstwie i współpracy UE-Rosja, a także uznania przez KE, że Rosja, ograniczając handel z jednym krajem, de facto łamała dotychczasowe porozumienie z UE jako całością [Ambroziak, Kawecka-Wyrzykowska 2004, Ambasador... 2007]. Ostatecznie w styczniu 2008 r., na podstawie porozumienia między Polską a Federacją Rosyjską, embargo na polskie produkty roślinne zostało zniesione, co pozwoliło na eksport polskich jabłek do Rosji [Rosja... 2008b].

Kolejne embargo łączone jest z działaniami Federacji Rosyjskiej na Ukrainie i zajęciem Krymu w lutym i marcu 2014 r. Szefowie rządów lub państw członkowskich UE 6 marca 2014 r. wydali oświadczenie, w którym postanowili zawiesić rozmowy dwustronne z Federacją Rosyjską w kwestiach wizowych, a także rozmowy na temat nowego porozumienia. W kolejnych miesiącach Rada UE przyjęła wiele decyzji dotyczących: a) zakazu wjazdu na terytorium państw członkowskich oraz zamrożenia wszelkich środków finansowych i zasobów gospodarczych dla kilkudziesięciu urzędników i podmiotów gospodarczych z Rosji, b) sankcji ekonomicznych w odniesieniu do niektórych sektorów gospodarki Rosji (handlu towarami podwójnego zastosowania, dostępu do rynku finansowego UE, c) zakazu przywozu do UE towarów pochodzących z Krymu i Sewastopola.

W odpowiedzi na te działania Federacja Rosyjska wprowadziła 6 sierpnia 2014 r. jednoroczny zakaz importu m.in. z państw członkowskich UE wybranych artykułów rolno-spożywczych, w tym jabłek (HS 080810). W związku z narastającym konfliktem zbrojnym między Ukrainą a Rosją w kolejnych miesiącach UE rozszerzała listę osób (do 147) i podmiotów gospodarczych (do 37) objętych sankcjami oraz wydłużyła obowiązywanie dotychczasowych ograniczeń, co spowodowało również przedłużenie obowiązywania nałożonych przez Rosję instrumentów ograniczających import m.in. jabłek z Polski.

Warto również zauważyć, że oprócz kwestii politycznych, powróciła w ostatnich latach sprawa wymagań fitosanitarnych. Już w kwietniu 2014 r. Rosyjska Federalna Służba Nadzoru Weterynaryjnego i Fitosanitarnego wskazywała na możliwość wprowadzenia zakazu wwożenia wyrobów o wysokim ryzyku fitosanitarnym z Polski oraz w ramach reeksportu przez kraje trzecie w związku ze znacznym przekroczeniem dopuszczalnych maksymalnych norm zawartości pestycydów i obecności azotanów [PAP 2014]. Ponadto już w trakcie nałożonego embarga Rosja krytycznie oceniała stopień bezpieczeństwa żywnościowego polskich jabłek [Miedwiediew... 2015]. 


\section{ZNACZENIE ORAZ POZYCJA POLSKI W EKSPORCIE JABŁEK Z PAŃSTW CZŁONKOWSKICH UE W LATACH 2004-2015}

W latach 2004-2015 państwa członkowskie UE wyeksportowały ogółem skumulowany wolumen 42,2 mln ton jabłek o wartości ponad 24,7 mld euro. Wśród nich Polska sprzedała za granicę 8,4 mln ton jabłek o wartości 2,6 mld euro, co dało jej odpowiednio drugie pod względem wolumenu (za Włochami) i czwarte (za Włochami, Francją i Holandią) miejsce pod względem wartości eksportu w ogólnej sprzedaży jabłek przez państwa członkowskie UE. Oznacza to, że Polska była jednym z najważniejszych eksporterów jabłek z UE, której udział w skumulowanej wielkości i wartości wyniósł odpowiednio 19,9 i 10,5\%. W latach 2004-2015 struktura geograficzna eksporterów unijnych zmieniała się dość radykalnie, nie tylko ze względu na działania rynku, ale również zewnętrzne bodźce w postaci środków handlowych nakładanych przez importerów (w tym embarga wprowadzane przez Rosję).

Analizując rynki zbytu, można stwierdzić, że w badanym okresie 2004-2015 ogólna (skumulowana) sprzedaż jabłek przez wszystkie państwa członkowskich UE na jednolitym rynku wewnętrznym była ponaddwukrotnie większa niż ich eksport poza UE i wyniosła $28,1 \mathrm{mln}$ ton (w stosunku do $14 \mathrm{mln}$ ton) jabłek o wartości 17,9 mld euro (w stosunku do 6,9 mln ton). Zdecydowanym liderem w wewnątrzunijnym handlu były Włochy, które sprzedały $7,5 \mathrm{mln}$ ton jabłek (co stanowiło $26,7 \%$ całej sprzedaży jabłek wewnątrz UE) o wartości 5,4 mld euro (co stanowiło 30,1\% ogólnej wartości sprzedaży wewnątrzunijnej). Drugie miejsce, z niewiele gorszymi wynikami, zajęła Francja, która w sumie sprzedała 5,9 mln ton jabłek $(21,0 \%)$ za kwotę 4,5 mld euro (25,3\%). Dopiero na piątym miejscu uplasowała się Polska, która sprzedała na rynku UE 2,6 mln ton jabłek $(9,1 \%)$ o wartości 0,8 mld euro $(4,7 \%)$.

Jednocześnie w tym samym okresie Polska stała się największym eksporterem jabłek poza granice UE, biorąc pod uwagę zarówno wartość, jak i wolumen $(5,8 \mathrm{mln}$ ton o wartości 1,8 mld euro). W dalszej kolejności były Włochy (2,4 mln ton o wartości 1,7 mld euro), Francja ( 2 mln ton o wartości 1,4 mld euro) oraz Litwa (1,4 mln ton o wartości 0,5 mld euro). Analiza udziałów w skumulowanej wartości i wolumenie eksportu ogółem poza UE pozwala stwierdzić, że Polska wyeksportowała 41,6\% jabłek sprzedanych z UE do państw trzecich w latach 2004-2015, jednak jej udział w wartości eksportu wyniósł zaledwie 25,6\%. Była to wartość niewiele większa od odsetka eksportu Włoch $(25,2 \%)$ i Francji (20,3\%), które wyeksportowały znacznie mniej jabłek (odpowiednio 16,9\% i 14,1\% sprzedaży poza UE ogółem) oraz Francji (20,3\%).

\section{KONSEKWENCJE DLA POLSKIEGO HANDLU JABŁEK WYNIKAJĄCE Z PIERWSZEGO EMBARGA FEDERACJI ROSYJSKIEJ}

Na początku badanego okresu, tj. w 2004 r., Polska sprzedała 433,5 tys. ton jabłek o wartości 90 mln euro, w tym poza UE 254,3 tys. ton, co stanowiło wówczas 46,4\% ogólnego eksportu jabłek UE do państw trzecich). Głównymi konkurentami Polski były Francja (101 tys. ton z udziałem 18,5\%), Włochy (58 tys. ton z odsetkiem 10,7\%) i Holandia (35 tys. ton z udziałem 6,3\%). Biorąc pod uwagę wartości eksportu, w 2004 r. francuski eksport jabłek był największy i osiągnął wartość 57,5 mln euro (co stanowiło 27,1\% wartości całej sprzedaży jabłek poza UE), na drugim miejscu polski na poziomie 48,7 mln euro (22,9\%), a dalej włoski: 33,6 mln euro (15,8\%) i holenderski: $24,4 \mathrm{mln}$ euro $(11,5 \%)$. 
Z punktu widzenia Polski w 2004 r. największym odbiorcą jabłek była Federacja Rosyjska (208,5 tys. ton o wartości 41,2 mln euro, co stanowiło odpowiednio 48,1 i 45,7\% ogólnego eksportu jabłek przez Polskę oraz 82,0 i 84,6\% eksportu Polski poza UE) (rys. 1. i 2.). W związku z tym, że embargo zostało nałożone pod koniec 2005 r., nie wpłynęło znacząco na ogólny wynik polskiego eksportu jabłek do Rosji w tym roku, dlatego odnotowano tylko nieznaczny spadek ilości (z 208,5 tys. ton w 2004 r. do 201,8 tys. ton w 2005 r.), a wartościowo - nastąpił nawet wzrost (z 41,2 mln euro w 2004 r. do 47,2 mln euro w 2005 r.). Jednak już kolejne dwa lata to prawie całkowite zamknięcie rynku rosyjskiego dla polskich jabłek. Ze względu na wolumen sprzedanych do Rosji jabłek w 2004 r. na drugim miejscu znalazła się Białoruś, a dalej Litwa, Rumunia, Słowacja i Łotwa (tab. 1. i 2.).

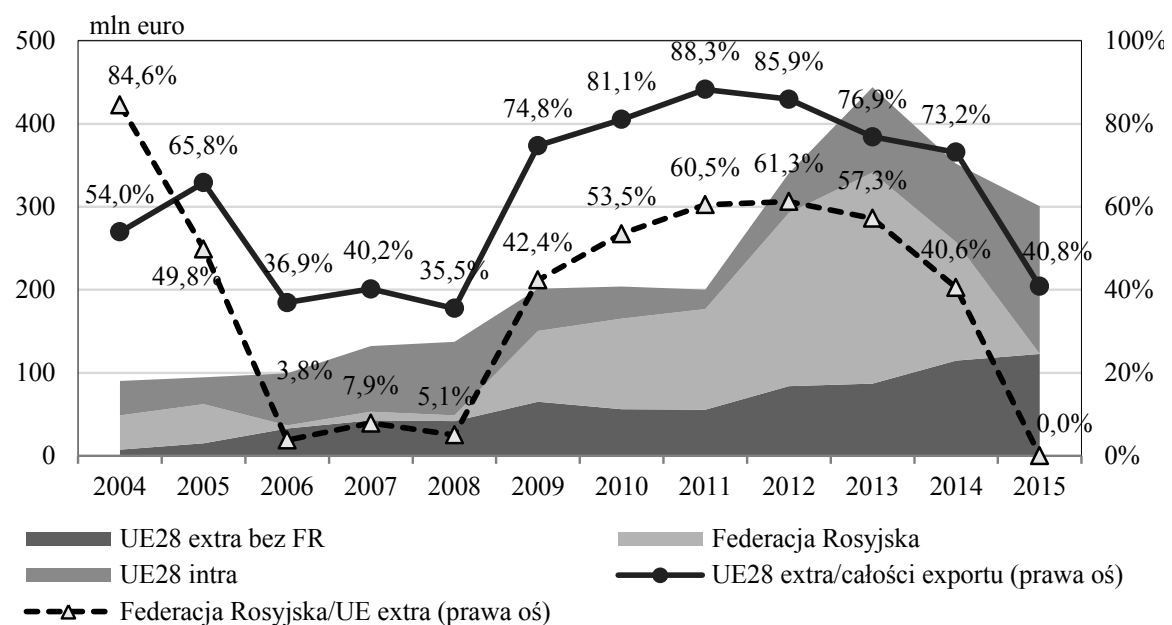

Rysunek 1. Wartość eksportu polskich jabłek w latach 2004-2015

Źródło: opracowanie własne na podstawie danych Eurostat.

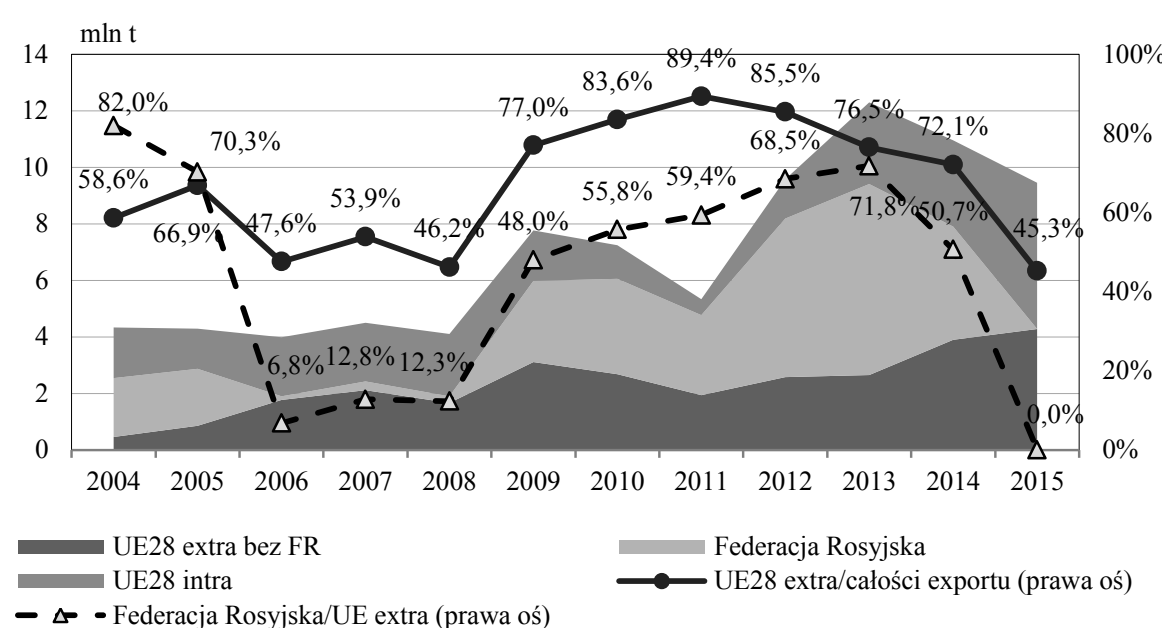

Rysunek 2. Wolumen eksportu polskich jabłek w latach 2004-2015

Źródło: opracowanie własne na podstawie danych Eurostat. 


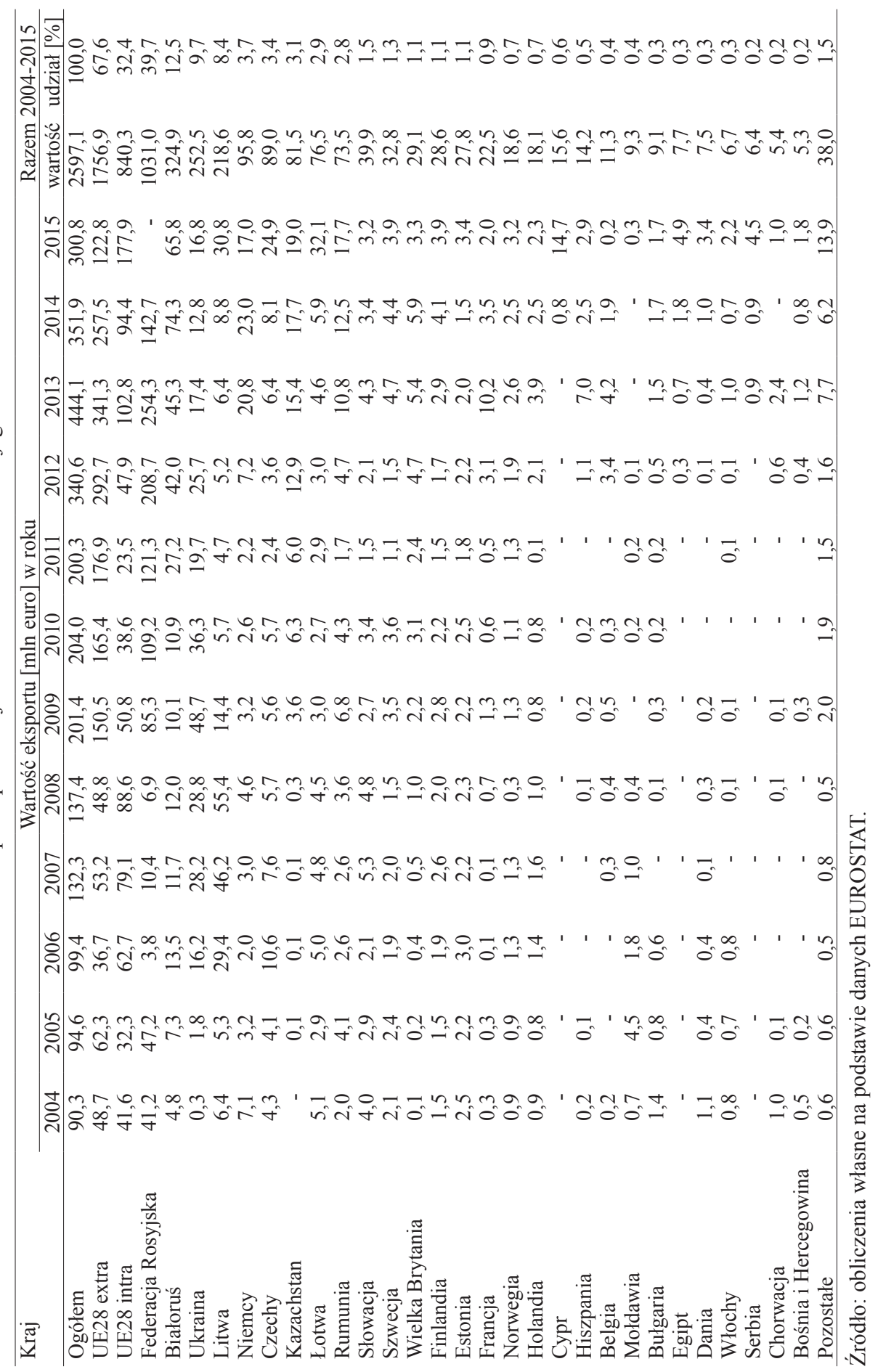




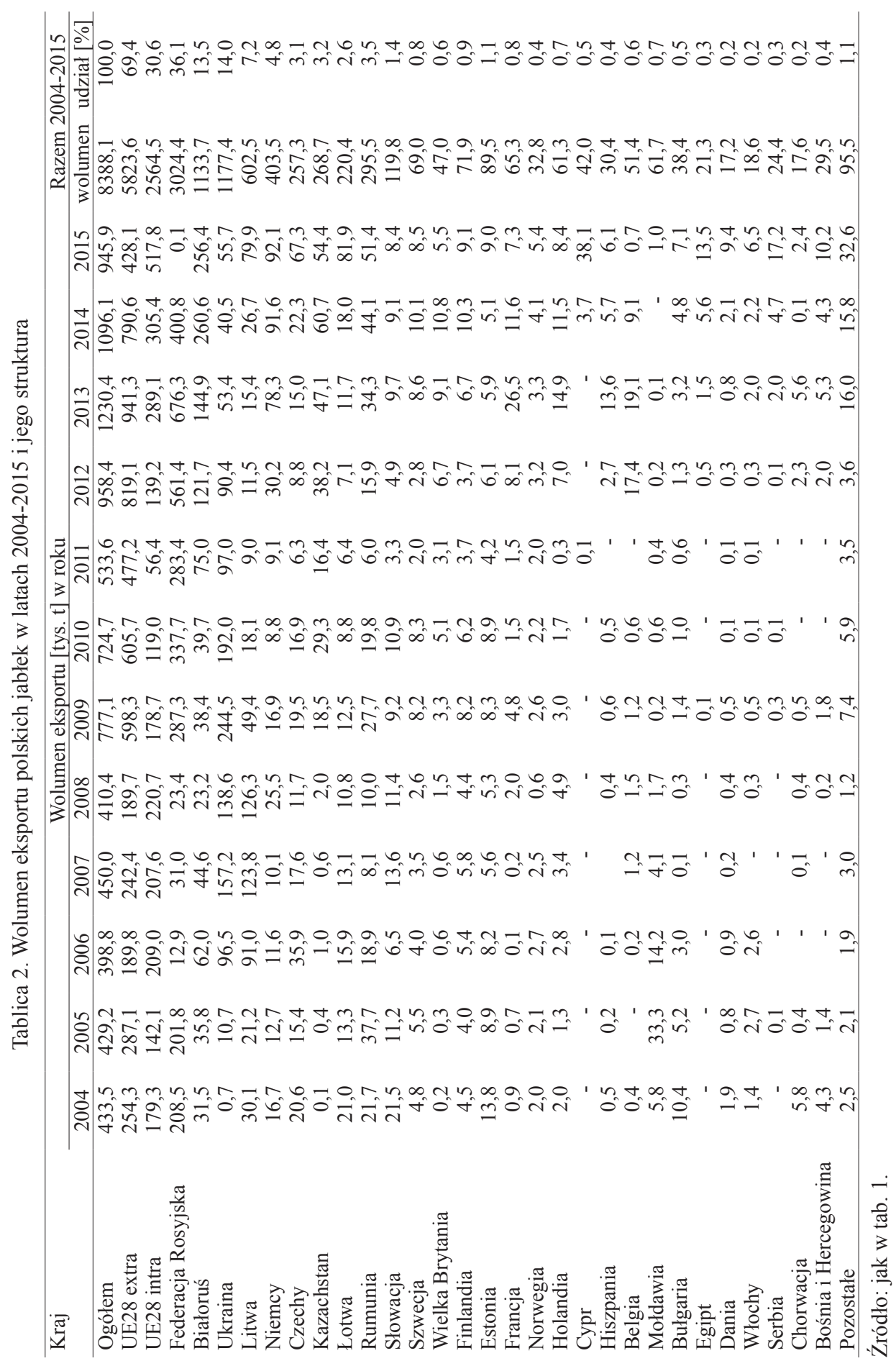


Gdy zaczęło obowiązywać pierwsze embargo Federacji Rosyjskiej na niektóre artykuły rolno-spożywcze z Polski, odnotowano relatywnie niewielkie spadki ogólnego polskiego eksportu tych artykułów - z 429,2 tys. ton w 2005 r. (o wartości 94,6 mln euro), przez 398,8 tys. ton w 2006 r. (za 99,4 mln euro), a następnie wzrost do 450 tys. ton w 2007 r. (132,3 mln euro).

Należy wyjaśnić, że ówczesne obostrzenia dotyczyły wyłącznie Polski, pozostawiając możliwość handlu z Rosją innym państwom członkowskim UE. W konsekwencji w okresie obowiązywania embarga zarejestrowano istotny wzrost sprzedaży polskich jabłek w ramach UE - ze 142,1 tys. ton (za 32,3 mln euro) w 2005 r. do 209 tys. ton (62,7 mln euro) w 2006 r. i aż do 207, tys. ton (79,1 mln euro) w 2007 r. Wynik ten był rezultatem zwiększonego eksportu polskich jabłek przede wszystkim na Litwę, która stała się ich reeksporterem na rynek rosyjski. W 2005 r. Polska sprzedała na Litwę zaledwie 21,2 tys. ton jabłek o wartości 5,3 mln euro, w 2006 r. zaś wielkość ta zwiększyła się już do 90 tys. ton za kwotę prawie 29,5 mln euro i w 2007 r. do 123 tys. ton za $46 \mathrm{mln}$ euro. W tych samych latach Rosja stała się najważniejszym odbiorcą jabłek litewskich (na poziomie 96-98\% całego eksportu jabłek z tego kraju). W latach 2006-2007 Litwa sprzedała wówczas odpowiednio 161 i 189 tys. ton jabłek (co stanowiło 55 i 65\% wielkości polskiej sprzedaży na Litwę). Potwierdza to doniesienie medialne, że znaczna część polskich jabłek trafiła właśnie przez Litwę i Łotwę na rynek rosyjski [Petz 2006].

W tym samym okresie w handlu z innymi państwami członkowskimi nie odnotowano znaczących zmian, wolumen sprzedaży polskich jabłek do Holandii wzrósł z 1,3 tys. ton w 2005 r. do 3,4 tys. ton w 2007 r., a do Wielkiej Brytanii odpowiednio z 0,3 do 0,6 tys. ton, a w niektórych przypadkach nawet spadał. Dotyczyło to takich państw, jak Rumunia, Szwecja, Francja, Estonia i Bułgaria. Niejednoznaczną poprawę konkurencyjności polskich jabłek na rynku unijnym, dzięki sprzedaży na Litwę, potwierdza zwiększenie się ujawnionej przewagi komparatywnej RCA (z 1,16 w 2004 r. do 1,65 w 2007 r.) oraz spadek wskaźnika Lafaya (z 5,59 w 2004 r. do 5,44 w 2008 r., tabela 3.). W tym samym okresie eksport polskich jabłek poza UE spadł z 287,1 tys. ton (62,3 mln euro) w 2005 r. do 189,7 tys. ton (36,7 mln euro) w 2006 r., aby wzrosnać do 242,4 tys. ton (48,8 mln euro) w 2007 r. Tak relatywnie słabe wyniki (w porównaniu do głównych konkurentów z państw członkowskich UE) potwierdzają wartości ujawnionej przewagi komparatywnej Polski na rynkach pozaunijnych (spadek RCA z 3,15 w 2004 r. do 1,84 w 2007 r. i indeksu Lafaya z 22,23 w 2004 r. do 16,05 w 2007 r., tabela 3.).

Niekorzystnych wyników nie zdołał zniwelować większy eksport do niektórych państw trzecich: na Białoruś i na Ukrainę. W przypadku Białorusi nastąpił znaczący wzrost sprzedaży w pierwszych dwóch latach embarga (z 35,7 tys. ton w 2005 r. do 62 tys. ton w 2006 r. i 44,6 tys. ton w 2007 r., aby następnie spaść do 23,1 tys. ton w 2008 r.). Znacznie większym odbiorcą polskich jabłek stała się Ukraina, do której eksport wzrósł ponaddziewięciokrotnie w pierwszym roku embarga (z 10,7 tys. ton w 2005 r. do 96,5 tys. ton w 2006 r., a następnie do 157 tys. ton w 2007 r.). W badanym podokresie polscy eksporterzy nie znaleźli stabilnych nowych rynków zbytu w sytuacji łatwości reeksportu jabłek do Rosji poprzez inne kraje. Pojawiły się pojedyncze większe dostawy, jednak miały one miejsce albo sporadycznie (np. do Azerbejdżanu), albo eksport rósł bardzo wolno (np. Kazachstan).

Ostatecznie wielkość eksportu jabłek z Polski w trakcie embarga rosyjskiego z 2005 r. radykalne nie zmalała w kolejnych latach w stosunku do roku bazowego, tj. 2004 r. Zatem wystąpił efekt przesunięcia wolumenu polskiego eksportu ze sprzedaży zagranicznej do Federacji Rosyjskiej na rzecz eksportu na Litwę, Białoruś i Ukrainę. Jednak embargo 
Tabela 3. Wartości wskaźnika przewagi komparatywnej RCA i wskaźnika Lafaya w eksporcie polskich jabłek wewnątrz (intra) oraz poza (extra) UE-28

\begin{tabular}{|c|c|c|c|c|c|c|c|c|c|c|c|c|}
\hline \multirow{2}{*}{$\begin{array}{l}\text { Nazwa } \\
\text { wskaźnika }\end{array}$} & \multicolumn{12}{|c|}{ Wielkości w roku } \\
\hline & 2004 & 2005 & 2006 & 2007 & 2008 & 2009 & 2010 & 2011 & 2012 & 2013 & 2014 & 2015 \\
\hline $\begin{array}{l}\text { RCA (intra } \\
\text { UE eksport) }\end{array}$ & 1,16 & 1,10 & 1,62 & 1,65 & 1,69 & 1,62 & 1,22 & 0,65 & 1,16 & 2,13 & 2,36 & 3,28 \\
\hline $\begin{array}{l}\text { Wskaźnik } \\
\text { Laffaya (intra } \\
\text { UE eksport) }\end{array}$ & 5 , & 3,92 & 6,35 & 5,44 & 6,20 & 5,30 & 3,42 & 0,52 & 3,24 & 7,43 & 6,66 & 10,17 \\
\hline $\begin{array}{l}\text { RCA (extra } \\
\text { UE eksport) }\end{array}$ & 3,15 & 3,22 & 2,00 & 1,84 & 1,65 & 2,69 & 2,80 & 2,33 & 2,39 & 2,86 & 2,51 & 2,06 \\
\hline $\begin{array}{l}\text { Wskaźnik } \\
\text { Laffaya (extra } \\
\text { UE eksport) }\end{array}$ & 22,23 & 24,77 & 17,72 & 16,05 & 16,18 & 22,56 & 23,19 & 21,95 & 15,90 & 18,58 & 22,36 & 24,44 \\
\hline
\end{tabular}

Źródło: jak w tab. 1.

nie pozwoliło na zwiększenie ogólnego eksportu w tym okresie, co spowodowało, że względna pozycja Polski wśród unijnych eksporterów jabłek zdecydowanie spadła. W 2006 r. - pierwszym pełnym roku obowiązywania embarga - odsetek sprzedaży polskich jabłek w eksporcie UE do państw trzecich mierzony w wolumenie sprzedaży spadł o 24,1 p.p. - do $22,3 \%$ w 2006 r. i 26,9\% w 2007 r. (w porównaniu do 2004 r.), mierzony zaś wartościowo (euro) zmniejszył się o 13,1 p.p. - do 9,8\% w 2006 r. i 12,2\% w 2007 r. Ówczesny spadek udziału Polski niemal w całości pokrył wzrost pozycji Litwy (ilościowo i wartościowo), co może wskazywać jedynie na substytucję geograficzną eksportera (polskie jabłka sprzedawane przez Litwę).

\section{ZMIANY W EKSPORCIE POLSKICH JABŁEK W ZWIĄZKU Z DRUGIM EMBARGIEM FEDERACJI ROSYJSKIEJ}

Po zniesieniu embarga przez Federację Rosyjską w 2008 r. zarówno wolumen, jak i wartość polskiego eksportu jabłek znacząco wzrosły przy relatywnie niewielkich zmianach sprzedaży innych głównych eksporterów z UE - Włoch i Francji oraz spadkach pozostałych państw członkowskich w porównaniu do poprzednich lat. W kolejnych latach 20092010 wzrosła przede wszystkim wartość i w niewielkim stopniu zmieniał się wolumen eksportu polskich jabłek. Najbardziej spektakularny spadek ilości sprzedawanych jabłek zaobserwowano w 2011 r. w porównaniu do 2010 r. - z 724,7 tys. ton do 533,6 tys. ton (głównie do Rosji - spadek z 337,7 tys. ton do 283,4 tys. ton, na Ukrainę spadek z 192 tys. ton do 97 tys. ton oraz do Kazachstanu, Rumunii, na Słowację). Nie był to jednak skutek instrumentów handlowych nakładanych przez partnerów, a jedynie słabych zbiorów w 2010 r. [Eksport... 2012). Jednocześnie wartość wyeksportowanych jabłek zmniejszyła się nieznacznie z 204 mln euro do 200,3 mln euro. Wynikało to z wyższych cen uzyskiwanych w krajach UE. Następne lata przyniosły dalszy wzrost pozycji Polski w eksporcie jabłek zarówno wewnątrz, jak i poza UE. W 2013 r. nastąpiła kulminacja polskiego eksportu jabłek w badanym okresie - 1230,4 tys. ton o wartości 444,1 mln euro (tab. 1. i 2.).

W 2013 r. Polska odnotowała wzrost wielkości eksportu poza UE do 941,3 tys. ton (oznaczało to wzrost 6,8 razy w porównaniu do 2004 r., co zapewniło najwyższy w okresie 
2004-2015 odsetek w ogólnym eksporcie UE na poziomie 62,4\%) o wartości 341,3 mln euro (wzrost ponadsiedmiokrotny, co stanowiło udział na poziomie 42,6\% wartości sprzedaży jabłek przez UE). Na kolejnym miejscu znalazły się Włochy, które w 2013 r. wyeksportowały poza UE zaledwie 200 tys. ton jabłek (13,9\% ogólnego wolumenu sprzedaży zagranicznej UE), ale o wartości 182 mln euro (co stanowiło 22,7\% udział w wartości eksportu UE). $\mathrm{Na}$ trzecim miejscu uplasowała się Francja z wynikiem sprzedaży jabłek poza granice UE na poziomie $155 \mathrm{mln}$ ton (co dało jej udział 10,3\% w wolumenie eksportu UE) za kwotę 182 mln euro (co stanowiło 16,0\% wartości sprzedaży UE).

Kolejne dwa lata, tj. 2014-2015, to okres obowiązywania drugiego embarga rosyjskiego, co w istotny sposób wpłynęło na kształt pozaunijnego eksportu Polski. Sprzedaż polskich jabłek do państw trzecich spadła do 790,6 tys. ton w 2014 r. (o wartości $257,5 \mathrm{mln}$ euro) oraz 428,1 tys. ton w 2015 r. (o wartości 122,8 mln euro). Jeszcze w latach 2012-2013 Rosja była dominującym odbiorcą. Jej udział w wartości pozaunijnej sprzedaży jabłek z Polski wzrósł do 68,5\% w 2012 r. i 71,8\% w 2013 r., co oznaczało zbliżenie do struktury sprzed poprzedniego embarga, gdy w 2004 r. wynosił 82,0\%, w 2005 r. zaś 70,3\%. Należy jednak podkreślić, że w tym samym czasie wolumen eksportu do Rosji był prawie trzykrotnie większy, wartość zaś pięciokrotnie wyższa niż przed pierwszym embargiem (676,3 tys. ton o wartości 254,3 mln euro w 2013 r.). Biorąc pod uwagę dynamikę wolumenu eksportu z lat 2012-2013 na poziomie 31\% oraz założenie utrzymujących się tych samych warunków produkcyjnych, można spodziewać się, że bez embarga w latach 2014-2015 eksport polskich jabłek do Rosji mógłby wynosić odpowiednio 879 tys. ton i 1142 tys. ton.

Drugim co do wielkości i wartości odbiorcą polskich jabłek była w tym czasie Białoruś. Eksport polskich jabłek do tego kraju wyniósł w 2013 r. 144,9 tys. ton o wartości 45,3 mln euro. W kolejnych latach w związku z nałożonym embargiem rosyjskim odnotowano wzrost do wysokości 256,4 tys. ton o wartości 65,8 mln euro w 2015 r. Zapewne część z tych dostaw była reeksportowana do Rosji. Na kolejnym miejscu należy wymienić eksport do Kazachstanu. W tym przypadku zaobserwowano w latach 2013 i 2014 w stosunku do 2012 r. wzrost eksportu polskich jabłek z 38,2 tys. ton do 47,1 tys. ton, a następnie do 60,7 tys. ton, ale potem spadek do 54,4 tys. ton w 2015 r., co mogło wynikać z zaostrzonej kontroli na granicy między Kazachstanem a Rosją [Rosja... 2014]. W związku z kryzysem gospodarczym na Ukrainie, silną deprecjacją hrywny względem euro, co spotęgowało spadek siły nabywczej ludności, pozycja Ukrainy w polskim eksporcie zmalała. Eksport polskich jabłek na Ukrainę obniżył się do 53,4 tys. ton (17,4 mln euro) w 2013 r., a następnie do 40,5 tys. ton (12,8 mln euro), aby nieco wzrosnąć w 2015 r. do poziomu 55,7 tys. ton (o wartości 16,8 mln euro).

W odniesieniu do pozostałych pozaunijnych importerów polskich jabłek należy wyróżnić dwie grupy państw - rzeczywistych i potencjalnych odbiorców. Pierwsze z nich to kraje, z którymi dotychczas Polska współpracowała w relatywnie niewielkiej skali, a w obliczu embarga zdecydowała się zintensyfikować współpracę (np. Norwegia, Egipt, Serbia, Bośnia i Hercegowina). Druga grupa to państwa, z którymi Polska dotychczas sporadycznie lub w ogóle nie handlowała, a obecnie odnotowuje się ich wzrost zainteresowania polskimi jabłkami. Dotyczy to Mongolii, Zjednoczonych Emiratów Arabskich, Czarnogóry, Gruzji, Hongkongu, Turcji oraz Tadżykistanu, ale także Arabii Saudyjskiej, Jordanii, Libanu, Indii, Iraku, Singapuru, Kosowa, Wietnamu, Nigerii, Armenii, Kuwejtu, Maroka, Kanady, Angoli, Senegalu i innych afrykańskich państw. Podejście takie znalazło odzwierciedlenie w ujawnionej przewadze komparatywnej polskiego eksportu jabłek poza UE w postaci rosnącego RCA (z 2,33 w 2011 r. do 2,51 w 2014 r.) oraz wskaźnika 
Lafaya (z 21,95 w 2011 r. do 22,36 w 2014 r., tabela 3.). Warto również zauważyć, że wzrost zainteresowania polskimi jabłkami w wielu krajach był skutkiem wzmożonej akcji promocyjnej i umów handlowych z poszczególnymi państwami.

W kontekście embarga rosyjskiego warto wskazać zmiany w sprzedaży polskich jabłek na jednolitym rynku europejskim. W 2009 r. nastąpił spadek zarówno wolumenu, jak i wartości sprzedaży jabłek w ramach UE prawie wszystkich głównych dostawców z państw członkowskich UE. Wówczas zainteresowanie polskich eksporterów rynkiem UE w porównaniu do eksportu poza UE zaczęło znacząco spadać: odsetek wolumenu i wartości sprzedaży na rynku wewnętrznym zmniejszył się odpowiednio do 10,6 i 11,7\% ogólnego eksportu polskich jabłek. Jednak lata 2011-2015 to okres relatywnie ważnych zmian w odniesieniu do roli rynku wewnętrznego dla sprzedaży polskich jabłek, która zwiększyła się o 146\% i wyniosła 289,1 tys. ton w 2013 r. (o wartości 102,8 mln ton) względem 139,2 tys. ton (o wartości 47,9 mln ton) rok wcześniej. W kolejnych latach, kiedy już embargo rosyjskie obowiązywało, nastąpił dalszy wzrost sprzedaży polskich jabłek na rynku UE do 305,4 tys. ton (94,4 mln euro) w 2014 r., a następnie do 517,8 tys. ton $(177,9$ mln euro) w $2015 \mathrm{r}$.

W związku z embargiem rosyjskim polscy eksporterzy jabłek zaczęli usilniej szukać rynku zbytu również w UE. Największym odbiorcą na rynku unijnym polskich jabłek stały się Niemcy (wzrost do 92,1 tys. ton o wartości 17,0 mln euro w 2015 r.), Rumunia (51,4 tys. ton o wartości 17,7 mln euro), Litwa (79,9 tys. ton o wartości $219 \mathrm{mln}$ euro), Czechy (67,3 tys. ton o wartości 24,9 mln euro). Warto zauważyć, że w badanym okresie zwiększyła się również rola mniejszych odbiorców: Łotwy i Cypru, choć nie była ona stabilna. Ten pozytywny trend wzrostowy rozpoczął się już w 2011 r. Zostało to potwierdzone przez wzrost wartości wskaźnika ujawnionej przewagi komparatywnej RCA sprzedaży polskich jabłek na rynku unijnym z 0,65 w 2011 r. do 3,28 w 2015 r. oraz indeksu Lafaya z 0,52 w 2011 r. do 10,17 w 2015 r.).

Embargo wpłynęło na ogólną pozycję Polski w eksporcie UE. Środki wprowadzone przez Rosję spowodowały zmniejszenie roli Polski w eksporcie zewnętrznym UE z ponad 62 do 24,7\%. Podobnie jak w przypadku embarga z lat 2005-2007, również i w tym okresie Litwa stała się liderem w wolumenie wyeksportowanych jabłek poza granice UE ze sprzedażą na poziomie 454 tys. ton (26,2\% eksportu UE) o wartości ponad 85 mln euro (10,2\% wartości sprzedaży UE), choć reeksport tych artykułów do Rosji raczej nie odbywał się. W tym samym czasie stopniowo rosła pozycja Włoch, których eksport jabłek poza UE zwiększył się ponadsześciokrotnie w 2015 r. w porównaniu do 2004 r. i osiągnął 431 tys. ton (16,9\% udział w eksporcie UE) o wartości 326 mln euro (co stanowiło 38,8\% wartości sprzedaży poza UE). Odnotowano zaś spadek znaczenia Francji, która wyeksportowała 183 tys. ton jabłek (a więc jedynie o 80\% więcej niż w 2004 r., co stanowiło 10,5\% eksportu unijnego) o wartości 160 mln euro (19\% wartości sprzedaży jabłek poza UE). Nastąpił też wzrost pozycji Polski na rynku unijnym: z udziału 2,4\% ogólnej sprzedaży wewnątrzunijnej jabłek w 2011 r. do 19,5\% w 2015 r. w wolumenie sprzedaży i z odpowiednio 1,5 do $10,7 \%$ w wartości sprzedaży. Dzięki temu Polska wyprzedziła w rankingu głównych sprzedawców z UE na rynku unijnym takie państwa jak Holandię i Belgię. Zdecydowanymi liderami wśród państw członkowskich UE dostarczającymi jabłka na rynek wewnętrzny pozostały Włochy i Francja, choć wielkość ich sprzedaży nieco spadła, a w konsekwencji udział odpowiednio 22,7 i 31,7\% w 2011 r. do 17,0 i 26,9\% w 2015 r., w porównaniu do nieco mniejszej obniżki pozycji tych państw w wartości sprzedaży: odpowiednio z 24,1 do $23,7 \%$ i z 35,0 do $32,3 \%$. 


\section{PODSUMOWANIE}

Analiza ograniczeń nakładanych na polski eksport jabłek do Federacji Rosyjskiej pozwala na sformułowanie kilku wniosków. Po pierwsze, embargo z 2005 r. zasadniczo różni się od tego z 2014 r., przede wszystkim zakresem państw nim objętych. W pierwszym przypadku dotyczyło to tylko Polski, co umożliwiło sprzedaż polskich jabłek na Litwę i Łotwę oraz ich reeksport do Rosji. Drugie embargo z 2014 r. nałożone na wszystkie państwa członkowskie UE wymusiło na polskich dostawcach inny system kompensaty wymiany handlowej.

Skupianie się wyłącznie na jednym rynku zbytu jest niebezpieczne, dlatego powinna następować dywersyfikacja rynków zbytu polskich producentów jabłek. Tak się jednak nie stało, gdyż po zniesieniu pierwszego omawianego embarga Federacja Rosyjska ponownie stała się głównym odbiorcą polskich jabłek. Rosja jest jednak bardzo specyficznym rynkiem zbytu, zarówno z politycznego, jak i gospodarczego punktu widzenia. Z jednej strony, wysoki poziom niestabilności politycznej i autorytarne rządy powodują relatywnie wysoki poziom niepewności dla dostawców różnych towarów. Z drugiej strony, ze względu na rozmiar i strukturę oraz zróżnicowanie dochodowe konsumentów rynek ten jest atrakcyjny dla dostawców zarówno podstawowych i tańszych towarów (często nieprzetworzonych rolno-spożywczych), jak i drogich dóbr luksusowych. Wydaje się, że dostawcy polskich jabłek do Rosji opierali się na bardzo dużym popycie importowym tego kraju i dostosowaniu polskich odmian do gustów i wymagań rosyjskich konsumentów (dominacja odmiany Idared, zapotrzebowanie na jabłka tej odmiany w innych państwach jest znacząco mniejsze).

W okresie embarga rosyjskiego z 2005 r. wielkość sprzedaży zagranicznej polskich jabłek utrzymała się dzięki handlowi z krajami spoza UE oraz z Litwą. Oznacza to, że w ramach rynku wewnętrznego mechanizm kompensaty handlu nie był skuteczny i efekt przesunięcia handlu na sprzedaż wewnątrzunijną był nieznaczny. Ponadto niektóre państwa członkowskie UE nawet zmniejszyły import jabłek z Polski. Należy bowiem pamiętać, że ówczesne embargo było argumentowane względami fitosanitarnymi i jakościowymi, co w pewnym (niewielkim jednak) stopniu podważało zaufanie konsumentów do polskich jabłek na rynku unijnym.

W przypadku drugiego embarga konieczne było poszukiwanie odbiorców nie tylko na rynku wewnętrznym UE, nie ograniczając się jedynie do Litwy, ale też na całym świecie. Zasadniczy wzrost eksportu na rynek UE, głównie do krajów UE-15, ale też do państw trzecich wymaga zmiany struktury odmianowej polskich jabłek, formowania dużych jednolitych partii owoców, lepszej organizacji rynku pierwotnego, poprawy logistyki sprzedaży, w tym w eksporcie do krajów pozaunijnych oraz przygotowania jabłek do dalekiego transportu. Jednak uzyskanie nowych zaświadczeń sanitarnych wymaganych na nowych rynkach jest długotrwałe i kosztowne, podobnie jak modernizacja sadownictwa w celu dostosowania asortymentu oferowanych artykułów do preferencji nowych konsumentów.

\section{LITERATURA}

Ambasador Niemiec, 2007: Polska stusznie postapiła ws. rosyjskiego embarga, http://wiadomosci. gazeta.pl/wiadomosci/1.114873.3840836.html, dostęp: 30.11.2016.

Ambroziak Adam A., Elżbieta Kawecka-Wyrzykowska, 2004: Traktatowe stosunki Unii Europejskiej z państwami trzecimi, [w] Unia Europejska, Tom I, red. Elżbieta Kawecka-Wyrzykowska, Ewa Synowiec, Instytut Koniunktur i Cen Handlu Zagranicznego, Warszawa. 
Ambroziak Łukasz, 2015: Wptyw rosyjskiego embarga na polski handel rolno-spożywczy, „Przemysł Spożywczy", t. 69, nr 7, s. 2-7.

Ambroziak Łukasz, Iwona Szczepaniak, 2014: Skutki rosyjskiego embarga na import produktów rolno-spożywczych, „Przemysł Spożywczy”, t. 68, nr 9, s. 2-8.

Balassa Bela, 1965: Trade Liberalization and "Revealed” Comparative Advantage, „The Manchester School of Economic and Social Studies", vol, 33(2), s. 99-123.

Baldwin David A. Robert A. Pape, 1998: Evaluating Economic Sanctions, „International Security”, vol. 23(2), s. 189-198.

Barber James, 1979: Economic Sanctions As a Policy Instrument, „International Affairs”, vol. 55(3), s. $367-384$.

Batyk Iwona M., 2014: Perspektywy rozwoju eksportu polskich produktów rolno-spożywczych do Rosji, „Zeszyty Naukowe SGGW w Warszawie. Problemy Rolnictwa Światowego”, t. 14, z. 3, s. 7-14.

Batyk Iwona M., 2015: Wpływ sankcji gospodarczych na strukturę polskiego eksportu produktów rolno-spożywczych do Rosji, „Studia i Prace Wydziału Nauk Ekonomicznych i Zarządzania”, nr 41, t. 1, s. 235-246.

Bierzanek Remigiusz, Janusz Symonides (red.), 2003: Prawo międzynarodowe publiczne, Lexis Nexis, Warszawa.

Błaszczuk-Zawiła Marzenna, 2014: Polsko-rosyjska wymiana handlowa w okresie członkostwa Polski w Unii Europejskiej, „Unia Europejska.pl”, nr 3(226), s. 16-29.

Bonetti Shane, 1998: Distinguishing Characteristics of Degree of Success and Failure in Economic Sanctions Episode, „Applied Economics”, vol. 30, s. 805-813.

Borowska Agnieszka, 2013: Zmiany na rynku jabłek w Polsce z uwzglednieniem jabtek regionalnych, „Roczniki Ekonomii Rolnictwa i Rozwoju Obszarów Wiejskich”, t. 100, z, 1, s. 152-167.

Borowska Agnieszka, 2014: Światowa sytuacja na rynku jabtek w latach 1961-2010, „Zeszyty Naukowe SGGW w Warszawie. Problemy Rolnictwa Światowego", t. 14, z, 2, s. 7-20.

Bugała Anna, 2014: Światowy rynek jabłek i zageszczonego soku jabłkowego, „Zeszyty Naukowe SGGW w Warszawie. Problemy Rolnictwa Swiatowego", t. 14, z, 2, s. 21-30.

Caruso Raul, 2003: The Impact of International Economic Sanctions on Trade, An Empirical Analysis, Paper prepared for the European Peace Science Conference, June 1-3 2003, Amsterdam, s. 1-29.

Cieślewicz Wiesława, 2012: Polski eksport produktów rolno-spożywczych do Rosji, „Zeszyty Naukowe SGGW w Warszawie. Problemy Rolnictwa Światowego", t. 12, z, 1, s. 18-30.

Czapliński Władysław, Anna Wyrozumska, 2004: Prawo międzynarodowe publiczne. Zagadnienia systemowe, C.H.Beck, Warszawa.

Czapliński Władysław, Anna Wyrozumska, 2014: Prawo międzynarodowe publiczne, Zagadnienia systemowe, C.H.Beck, Warszawa.

Drążek Monika, Mariusz Dziwulski, Anna Kitala, Michał Koleśnikow, Marta Skrzypczyk, 2015: Wplyw ograniczeń handlowych wprowadzanych przez Rosję na sektor-rolno-spożywczy w Polsce, Raport Banku BGŻ BNP Paribas w rocznicę rosyjskiego embarga.

Drezner Daniel W., 2000: Bargaining, Enforcement, and Multilateral Sanctions: When Is Cooperation Counterproductive? „International Organisation”, vol. 54(1), s. 73-102.

Eksport jabłek z Polski w 2011 roku. 2011: http://www,fresh-market,pl/owoce i_warzywa/owoce/ jablka/eksport jablek_z polski_w_2011_roku,p137310279, dostęp: 6.12.2016.

Fedoseeva Svetlana, 2016: Russian Agricultural Import Ban: Quantifying Losses of German Agri-Food Exporters, Institute for Agricultural Policy and Market Research, Justus Liebig University, Giessen, Germany.

Forsberg Tuomas, Aantti Seppo, 2009: Power without Influence? The EU and Trade Disputes with Russia Federation, „Europe-Asia Studies”, 61(10), s. 1805-1823.

Grzegorzewska Emilia, 2014: Konflikt rosyjsko-ukraiński a wybrane aspekty ryzyka działalności rolniczej w Polsce, „Roczniki Naukowe Ekonomii Rolnictwa i Rozwoju Obszarów Wiejskich”, t. 101, z. 4, s. 46-53.

Horska Elena, Moroz Serhiy, Galova Jana, 2016: The EU - Ukraine - Russia Crisis Triangle: Evidence of Local and Global Consequences for International Trade, [w] Global Perspectives on Trade Integration and Economies in Transition, red. Vasily Erokhin, Business Science Reference, Hershey, s. 105-125.

Keohane Robert O., Joseph S. Nye, 1987: Power and Interdependence Revisited, „International Organization", vol. 41(4), s. 725-753. 
Kholodilin Konstantin, Dirk Ulbricht, Georg Wagner, 2014: Are the Economic Sanctions against Russia Effective? DIW Roundup, Politik im Fokus, Deutsches Institute für Wirtschaftsforschung.

Kraatz Susanne, 2014: The Russian Embargo: Impact on the Economic and Employment Situation in the EU, European Parlament, Policy Department A, Economy and Scientific Policy.

Kraciński Paweł, 2015: Unijny eksport produktów ogrodniczych do Rosji w latach 2004-2013, „Roczniki Naukowe Ekonomii Rolnictwa i Rozwoju Obszarów Wiejskich”, t. 102, z, 4. s. 60-66.

Kutlina-Dimitrova Zornitsa, 2015: The Economic Impact of the Russian Import Ban: a CGE Analysis, Chief Economist Note, DG Trade, European Commission, Issue 3.

Lafay Gérard, 1992: The Measurement of Revealed Comparative Advantages, [w] International Trade Modeling, red. Marcel G. Dagenais, Pierre-Alain Muet, Chapman \& Hill, London.

Malchar-Michalska Dominika, 2012: Wpływ kryzysu żywnościowego na wykorzystanie ograniczeń eksportowych w handlu międzynarodowym surowcami rolnymi, „Prace Naukowe Uniwersytetu Ekonomicznego we Wrocławiu", nr 267, s. 39-48.

Malchar-Michalska Dominika, 2014: Polski eksport owoców i przetworów z owoców w latach 20012012, „Prace Naukowe Uniwersytetu Ekonomicznego we Wrocławiu”, nr 369, s. 320-332.

Matysik-Pejas Renata, Monika Szafrańska, Agnieszka Potocka, 2010: Stan i uwarunkowania wymiany handlowej Polski z Rosja w zakresie produktów rolno-spożywczych, ,Zeszyty Naukowe SGGW w Warszawie. Problemy Rolnictwa Światowego", t. 10, z. 2, s. 80-90.

Mayall James, 1984: The Sanctions Problem in International Economic Relations: Reflections in the Light of Recent Experience, ,International Affairs”, vol. 60(4), s. 631-642.

Michalczyk Joanna, 2012: Bezpieczeństwo żywnościowe wobliczu globalizacji, „Ekonomia”, 18(1), s. 9-23.

Miedwiediew o polskich jabtkach: ,,Polacy oblewaja je chemikaliami”, 2015: http://wiadomosci,gazeta,pl/wiadomosci/1,114871,18541585,miedwiediew-o-polskich-jablkach-polacy-oblewaja-je-chemikaliami,html, dostęp: 30.11.2016.

Morgan T. Clifton, Valerie L. Schebach, 1997: Fool Suffer Gladly: The Use of Economic Sanctions in International Crises, „International Studies Quarterly”, vol. 41(1), s. 27-50.

Mroczek Wojciech, 2014: Silna wspótzależność gospodarek Unii Europejskiej i Rosji-powiazania handlowe, „Unia Europejska,pl”, nr 224(1), s. 3-7.

Nacewicz-Twardowska Aleksandra, 2015: Wplyw sankcji rosyjskich na wymianę towarowa Polski, „Prace Naukowe Uniwersytetu Ekonomicznego we Wrocławiu”, nr 402, s, 220-230.

Nacewicz-Twardowska Aleksandra, 2016: Wpływ kryzysu rosyjsko-ukraińskiego na wymiane towarowa Polski i innych krajów unijnych, „Zeszyty Naukowe Uniwersytetu Ekonomicznego w Katowicach. Studia Ekonomiczne”, nr 266, s. 155-166.

Odpowiedź ministra rolnictwa i rozwoju wsi na interpelację $n r 1956$ w sprawie działań Ministerstwa Rolnictwa i Rozwoju Wsi majacych na celu przełamywanie rosyjskiego embarga na polskie jabtka, 2006: http://orka2,sejm,gov,pl/IZ5,nsf/main/4B53F50B, dostęp: 30.11.2016.

PAP, 2014: Rosja może zakazać importu z Polski owoców, warzyw i jagód, 22 kwietnia 2014 r., http://wyborcza,pl/1,91446,15837539,Rosja_moze_zakazac_importu_z_Polski_owocow_warzyw,html, dostęp 2016-11,30.

Pape Robert A., 1997: Why Economic Sanctions Do not Work, „International Security”, vol. 22(2), s. $90-136$.

Pawlak Karolina, 2015: Polsko-rosyjski handel produktami rolno-żywnościowymi po akcesji Polski do Unii Europejskiej, „Prace Naukowe Uniwersytetu Ekonomicznego we Wrocławiu”, nr 407, 327-340.

Petz Janusz, 2006: Jabtka jada do Rosji przez Łotwę, echodnia,eu, http://www,echodnia,eu/radomskie/gospodarka/art/8256302,jablka-jada-do-rosji-przez-lotwe,id,t,html, dostęp: 8.12.2016.

Porter Richard C., 1979: International Trade and Investment Sanctions: Potential Impact on the South African Economy, „The Journal of Conflict Resolution”, vol. 23(4), s. 579-612.

Rosińska-Bukowska Magdalena, 2015: Handel rolno-spożywczy UE-Rosja-efekty rosyjskich sankcji, „Zeszyty Naukowe SGGW w Warszawie. Problemy Rolnictwa Światowego”, t. 15(1), s. 113-124.

Rosja nie odpuszcza embarga na owoce, 2008a: echodnia,eu, http://www,echodnia,eu/radomskie/ gospodarka/art/8361502,rosja-nie-odpuszcza-embarga-na-owoce,id,t,html, dostęp: 20.11.2016.

Rosja zniosła embargo na polskie produkty roślinne, 2008b: http://wiadomosci,gazeta,pl/wiadomosci/1,114873,4851559, html, dostęp: 30.11.2016.

Rosja, Udaremniono wwóz 21 ton polskich jabłek do obwodu omskiego, 2014: http://wyborcza. pl/1,91446,16928188.Rosja_Udaremniono_wwoz_21_ton_polskich_jablek_do_obwodu,html, dostęp: 30.11.2016. 
Smutka Lubos, Jindrich Spicka, Natalia Ischukova, Richard Selby, 2016: Agrarian import ban and its impact on the Russian and European Union agrarian trade performance, „Agricultural Economics", 62(11), s. 493-506.

Tsebelis George, 1990: Are Sanctions Effective? Game-theoretic analysis of sanctions, „Journal of Conflict Resolutions", vol. 34(1), s. 3-29.

van Bergeijk Peter A.G. (red.), 1994: Economic diplomacy, trade and commercial policy: positive and negative sanctions in a new world order. Aldershot, Edward Elgar.

van Bergeijk Peter A.G., 1989: Success and failure of economic sanctions, „Kyklos”, vol. 42(3), s. 385-404.

Wagner R. Harrison, 1988: Economic Interdependence, Bargaining Power and Political Influence, „International Organization”, vol. 42(3), s. 461-483.

Wiśniewska Marta, 2005: Sankcje ekonomiczne Unii Europejskiej, „Studia Europejskie”, vol. 2, s. $29-43$.

\title{
Adam A. Ambroziak \\ ECONOMIC AND FINANCIAL RESULTS OF FARMS WITH FIELD CROPS \\ IN COMPARISON TO FARMS FOCUSED ON OTHER CROPS AND FARMS IN POLAND \\ IN GENERAL BASED ON POLISH FADN DATA
}

\begin{abstract}
Summary
The paper presents the economic and financial results of farms focused on cultivation of field crops in comparison to farms oriented on the rest of plant production (horticulture, permanent crops) and farms in Poland in general. The basis for the study was data for the years 2013 and 2014 collected in these farms under the system of Polish FADN. It was shown that the farms in which cultivation of field crops (mainly cereals and rape) is dominant in the total production were characterized by, on average, 20\% higher income than farms in general. In terms of income, however, horticultural holdings dominated. Some differences across FADN regions were observed. Horticultural holdings were characterized by relatively low value of obtained subsidies which in other types of vegetable farms and in farms in general had a significant impact on earned income.
\end{abstract}

Adres do korespondencji: Dr hab. Adam A. Ambroziak Szkoła Główna Handlowa w Warszawie Katedra Integracji Europejskiej im. J. Monneta al. Niepodległości 162, 02-554 Warszawa e-mail: adam.ambroziak@sgh.waw.pl

\section{PODZIĘKOWANIA}

Szczególne podziękowania należą się Panu prof. dr hab. Zdzisławowi Wyszyńskiemu, Dziekanowi Wydziału Rolnictwa i Biologii SGGW za inspirację tematyczną, Panom dr Januszowi Rowińskiemu, wieloletniemu pracownikowi Urzędu Komitetu Integracji Europejskiej oraz Instytutu Ekonomiki Rolnictwa i Gospodarki Żywnościowej-PIB oraz dr Łukaszowi Ambroziakowi z Instytutu Ekonomiki Rolnictwa i Gospodarki Żywnościowej-PIB za wszystkie uwagi i komentarze do niniejszego opracowania na jego wcześniejszym etapie, a także Recenzentom za cenne i trafne spostrzeżenia, komentarze i propozycje zmian, których wprowadzenie przyczyniło się do poprawy jakości i czytelności tekstu. 